Intersections

Canadian Journal of Music

Revue canadienne de musique
Intersections CANADIAN JOURAL OF MUSIC

\title{
Developing Variation in Gilles Tremblay's Croissant: Transformation and Identity
}

\section{Stephanie Lind}

Volume 37, numéro 2, 2017

URI : https://id.erudit.org/iderudit/1066619ar

DOI : https://doi.org/10.7202/1066619ar

Aller au sommaire du numéro

\section{Éditeur(s)}

Canadian University Music Society / Société de musique des universités canadiennes

ISSN

1911-0146 (imprimé)

1918-512X (numérique)

Découvrir la revue

Citer cet article

Lind, S. (2017). Developing Variation in Gilles Tremblay's Croissant:

Transformation and Identity. Intersections, 37(2), 73-99.

https://doi.org/10.7202/1066619ar

\section{Résumé de l'article}

Gilles Tremblay, considéré comme l'un des précurseurs de la musique contemporaine au Québec, est d'abord connu pour son attention au rythme, à la sonorité, et aux processus aléatoires. Cet article explore un aspect ignoré de la technique compositionnelle de Tremblay : le développement motivique par variation développante. À partir d'une discussion sur les antécédents historiques de ce style dans l'oeuvre de Schoenberg, d'Indy, et Dutilleux, cet article analyse l'utilisation faite par Tremblay de la variation développante dans son quatuor à cordes, Croissant, à travers le prisme de la théorie transformationnelle.
Copyright (c) Canadian University Music Society / Société de musique des universités canadiennes, 2019
Ce document est protégé par la loi sur le droit d'auteur. L'utilisation des services d'Érudit (y compris la reproduction) est assujettie à sa politique d'utilisation que vous pouvez consulter en ligne.

https://apropos.erudit.org/fr/usagers/politique-dutilisation/ 


\title{
DEVELOPING VARIATION IN GILLES TREMBLAY'S CROISSANT: TRANSFORMATION AND IDENTITY
}

\author{
Stephanie Lind ${ }^{1}$
}

\section{INTRODUCTION}

Gilles Tremblay passed away at the age of eighty-five on 27 July 2017. He was considered "one of the major figures in Quebec contemporary music" (SMCQ 2017), and his impact on the Quebec music scene cannot be understated. As a pedagogue, he taught many of Quebec's most renowned composers during his thirty-seven years at the Conservatoire de musique de Montréal, including Walter Boudreau, Micheline Coulombe Saint-Marcoux, Yves Daoust, Jean Lesage, Isabelle Panneton, Serge Provost, and Claude Vivier. As a supporter of contemporary art music, Tremblay was active in a variety of roles within the Société de musique contemporaine du Québec, including president, artistic director, and member of the board of directors (SMCQ 2017; Richard 2006). As a cultural icon in Quebec, Tremblay publicly withdrew his nomination to the Order of Canada in 1982 to protest Quebec's omission from the recent repatriation of Canada's constitution (Tremblay 1994), a significant gesture supporting Quebec's status as a distinct nation. ${ }^{2}$

Tremblay was also well known in the rest of Canada through his participation in the Canadian League of Composers, as an associate composer with the Canadian Music Centre, and as an adviser for the Canada Council; he was awarded the Prix Calixa Lavallée for his compositional work on the Quebec pavilion at Expo '67 (CMC 2003). Tremblay spent 1954-61 studying and working in Europe, during which time he met and worked with Europe's leading contemporary composers, including Karlheinz Stockhausen, Pierre Boulez, Henri Pousseur, and Pierre Schaeffer (SMCQ n.d.; Richard 2006). Most notably, during that time Tremblay studied with Olivier Messiaen, who is considered one of his main influences. His style bears a surprising affinity to that of Messiaen in his strong focus on tone colour, rhythmic organization, layering of textural streams, and use of symmetrical pitch materials including Messiaen's modes of limited transposition (Lind 2008b, 99).

1 The author would like to thank the estate of Gilles Tremblay and the Canadian Music Centre for kind permission to reprint excerpts from Phases-Réseaux and Croissant within this article.

2 Tremblay would later accept the Order of Canada award in 2012 (SMCQ 2012). 
Stylistically Tremblay is often cited for two characteristic features: his use of "en mobile" style, a type of aleatoric composition with motivic cells specifying an element such as dynamics, pitch, or contour played in the desired order of the performer (figure 1); and "en reflexe" style, where the performer reacts to musical gestures from other musicians within the ensemble (figure 2). Tremblay is also cited for his focus on tone colour and sonority; as Robert Richard describes it, "The aesthetic of Gilles Tremblay is concerned above all with sonority... . Far from referring solely to original combinations of timbres, the word should invite us to consider sound as a complex network of events, both material and immaterial, real and potential" (Richard 2006). On the other hand, Tremblay himself described rhythm as the essence of all music (Messier and Messier 2006), and frequently spoke about how rhythm itself creates pitch: "If you listen to the streams, the rivers, the falls, it's full of rhythm, and if you slow down these things, then you are conscious of the fantastic rhythms, when it's slowed down. If you slowed down two octaves, it's like many gamelans or an orchestra of Indian tablas, making very intricate, beautiful rhythms" (Cornfield 2003). Rhythm, pitch, and sonority are closely integrated in Tremblay's music.

Despite a strong focus on rhythm, sonority, and aleatoric processes, Tremblay also employs more traditionally notated passages specifying precise pitch and rhythm. While Tremblay's writings on both his own composition and the works of other modernist composers are quite extensive (see Lefebvre 2011 for a comprehensive listing), only a few analyses have examined Tremblay's pitch organization and development, most notably Serge Provost's analysis of

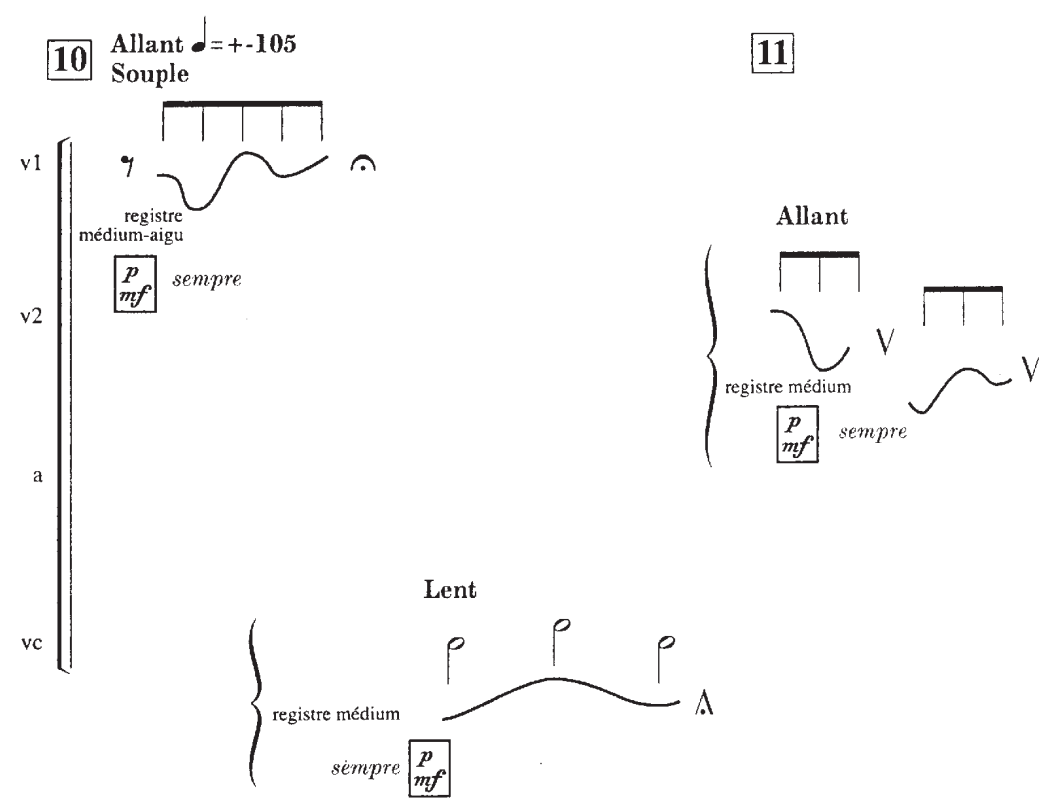

Figure 1. An example of the "en mobile" style from Croissant. 


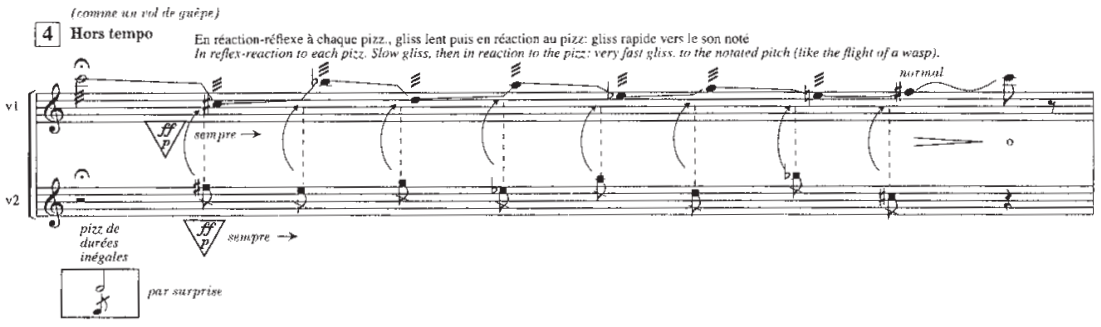

Figure 2. An example of the "en reflexe" style from Croissant.

serial organization and derivation in Réseaux (Provost 2011), Vincent Ranallo's examination of Gregorian chant in Oralléluiants (Ranallo 2011), and Tremblay's own published descriptions of Cantique de durées and Vêpres de la Vierge (Tremblay 1995b, 1995c), describing how he generates rhythm from pitch, and how he ornaments chant-based melodies, respectively. This article will instead examine another, unexplored aspect of Tremblay's composition: motivic development through developing variation. While admittedly a minor focus of his compositional process, developing variation is a useful tool for analyzing pitch, rhythm, and contour, as well as their interrelationships, within Tremblay's Croissant, composed in 2001 for string quartet.

\section{What Is Developing Variation: Roots in SChOenberg AND BRAHMS}

Developing variation is not often identified with composers from the French tradition, instead being more strongly linked to Germanic composers. Most often associated with the music of Johannes Brahms, developing variation was a particular interest of Arnold Schoenberg from both a musicological and pedagogical perspective.

Schoenberg speaks about variation in several sources, but his definition of developing variation is often ambiguous. However, hints of his intent can be found in several of his writings. In his 1931 radio talk on his Orchestral Variations, Schoenberg argues that "a stricter style of composition ... demands that nothing be repeated without promoting the development of the music, and that can only happen by way of far-reaching variations" (Schoenberg 1960, 28). In Letters Schoenberg identifies that "music with a main theme, accompanied by and based on harmony, produces its material by, as I call it, developing variation. This means that variation of the features of a basic unit produces all the thematic formulations which provide for fluency, contrasts, variety, logic and unity on the one hand, and character, mood, expression, and every needed differentiation, on the other hand" (Schoenberg 1965, as cited by Frisch 1984, 1-2). In his discussion of Brahms in Fundamentals of Musical Composition, Schoenberg alludes to another element of developing variation, the mutation of the theme over successive variation: "Brahms frequently produces new skeletons by changing the viewpoint as to which are the main features and which are subordinate" (Schoenberg 1967, 171). Conversely, Schoenberg occasionally 
identifies what developing variation is not: it is not "unvaried repetitions of a few phrases," and it is the antithesis of counterpoint (Schoenberg 1975, 186-7, 212). Nevertheless, while Schoenberg's writings provide a relatively thorough idea of what developing variation does, they do not thoroughly answer the question of what developing variation is; as Walter Frisch observes, Schoenberg's references to developing variation occur "only sporadically, and often aphoristically" (Frisch 1984, 1; Frisch 1992, 215-216 and 221).

Later scholars provide a much more refined definition of developing variation. Carl Dahlhaus, in his study of Schoenberg and Brahms, more concisely defines it as "the process whereby a second motif derives from a first, and a third from the second," with the significant caveat that this "does not always imply that the third is still connected with the first by means of some common feature" (Dahlhaus 1987, 132). ${ }^{3}$ As a result, developing variation involves more abstraction than is typical with the simple working of a theme (131). The result is a process of organicism, where form arises from motivic development rather than a pre-assumed set of formal relations (Dahlhaus via Frisch 1984, 27). Haimo's study of developing variation in Schoenberg further supports this idea of organicism, although he uses the term teleological rather than organic in his description: "Developing variation is a special category of variation technique, one that implies a teleological process. As a result, later events-even markedly contrasting ones-can be understood to originate from, or grow out of, changes that were made in the repetitions of earlier musical units" (Haimo 1997, 351).

Frisch, in his landmark study of developing variation in Brahms's composition, finds support for organicism from Brahms himself, who, in correspondence with his student Gustav Jenner, contends that "one has not written a sonata if one holds together a few ideas merely with the outward form of a sonata; on the contrary, the sonata form must of necessity result from the idea" (Frisch 1984, 34). Furthermore, a compatibility with Schoenbergian notions of developing variation is suggested by Josef Rufer. In his Composition with Twelve Notes, a study of twelve-tone methodology inspired by his work with Schoenberg as both student and assistant (and begun in collaboration with Schoenberg before being untimely interrupted by the latter's death), Rufer identifies the same organicism in his definition of developing variation: "In artforms repetitions of motifs are varied in proportion to their formal functions, and thus contribute to the development of the work .... Repetition combined with variation allows the unit to create the manifold by procreating new shapes through 'developing variation'” (Rufer 1954, 26).

While allusions to developing variation are peppered throughout both historical and contemporary writings, the term for this concept varies considerably

3 Ethan Haimo similarly defines developing variation as: "1) an initial motivic figure is stated; 2) this is followed by another figure that retains enough of the features of the first to be recognised, at least in some dimensions, as a restatement of that figure, but with significant changes in other dimensions; 3 ) those changes effectively create new musical configurations which can then be subjected to further development by restatement combined with variation" (Haimo 1997, 355). Haimo's work, an extended study of Schoenberg's usage of developing variation in his own repertoire, provides a good overview of Schoenberg's usage of the term. 
among scholars and composers. Julius Schäffer, a contemporary of Brahms, outlines three types of variation. His third category of variation fits comfortably within Dahlhaus's conceptualization of developing variation:

In the third class [of variation], the point lies neither in the theme alone, nor in the Variations alone, but in the psychological relation between the two. That is the germ, these the developing phases of what goes on within. That the theme here is commonly a sentence or musical proposition invented by the composer himself-an original theme so-called-lies altogether in the nature of the case. The single variations will have to show their connection with the theme, as well as with one another, the latter naturally by the fact that one leads immediately into another (although this is not strictly necessary). Moreover, with their new-born motives, they will also bring with them new laws of development, and so develop into independent art-forms; indeed they will frequently draw into their domain related passages, or Intermezzi, not derived directly from the theme-as in Schumann's Variations for two pianos. While the Variation form in this kind reaches its highest significance, it has at the same time arrived at its extreme limit; it strives to overstep this and pass out into the domain of free Fantasia. Hence it seems not inappropriate to give it the name of Phantasie-Variations, just as we say, Sonata quasi Fantasie, Polonaise-Fantaisie, Impromptu-Fantaisie, \&c. (Schäffer 1860, 105-6)

While he names the compositional process "Fantasy-Variations," the concept of organic growth is core to this definition. In another example, Frisch observes that Rudolf Réti, a Serbian composer who was an active promoter of Schoenberg's music in 1910 S Vienna, employs the term thematic transformation in lieu of developing variation in his historical survey of motivic process in Western music, The Thematic Process in Music, published in 1951 (Frisch 1984, 22). More recently, American composer and theorist Fred Lerdahl describes a process he names expanding variation. Inspired by his work on the seminal text A Generative Theory of Tonal Music with Ray Jackendoff, he recounts,

While working with Jackendoff I did many reductional analyses of tonal pieces, some of which appeared in GTTM, in order to test and refine the rules that we were formulating. This activity led to the notion of composing by "expanding variations," which constituted a kind of reduction in reverse, spread over time. The idea was to begin with a single, stable event and elaborate it progressively into a few events, then more events, and eventually many events covering many minutes. As the events were elaborated, the complex would gradually become highly unstable. The materials themselves would not be the standard tonal ones but materials of my own devising .... In expanding variations, any given variation is elaborated within the structure of the previous variation, yet how it is elaborated is not predetermined. Once the variation is realized, it in turn sets the framework within which the next variation evolves. (Lerdahl 1999, 244-5) 
While Lerdahl's approach differs from the other variation forms described in this article, 4 the idea of organicism is clearly present: one variation of a motive influences subsequent variation procedures. This progressive evolution of motive-forms seems a natural consequence of the emphasis in A Generative Theory of Tonal Music on hierarchical relationships, and that these result from the elaboration of one musical event to another (Lerdahl and Jackendoff 1985, $112-13)$.

\section{Developing Variation in the French Tradition}

Developing variation was not unknown among French-language composers, although, like Lerdahl and Réti, the terminology used to describe the concept fluctuates. French composer Vincent d'Indy identifies a form of variation suggestive of developing variation:

Celle-ci [la variation], toutefois, n’a point renoncé à ses droits: recueillant en une nouvelle forme les éléments ornementaux et décoratifs, elle en a fait la Variation amplificatrice, qui semble cumuler en elle-même toutes les forces musicales de la Variation, du développement et de la transformation cyclique. Et ce nouvel avatar de la Variation, qui a tué l'Air varié, pourrait bien aboutir dans l'avenir à une rénovation profonde des formes de notre art. ${ }^{5}$

The remainder of d'Indy's chapter suggests that variation amplificatrice covers a much broader definition of variation, essentially that which combines aspects of both development and ornamentation (including, for example, modulation). Nonetheless, the emphasis on development and transformation here suggests that variation amplificatrice refers to developing variation. Techniques of development and variation also occur in the music of Henri Dutilleux. Dutilleux identifies a concept he calls croissance progressive (progressive growth), defined as the use of small motivic cells that develop gradually over time. Citing Proust as an influence, he states, "This element undergoes a succession of changes, of metamorphoses, until, after a certain number of them, as with insects, you find that there's an essential change in its nature: the original idea is almost unrecognizable" (Nichols and Dutilleux 1994, 89 via Hesketh 2010, 464).

Unlike traditional variation, Dutilleux's process recognizes the inherent change in the motive throughout the variation process: the connection between the original idea and the final idea is not necessarily recognizable without tracing the path of development itself. This mirrors Dahlhaus's definition.

4 Specifically, Lerdahl's variations retain the original motive as a frame for the newly inserted content rather than having this original motive disappear over the course of motivic development.

5 "This one [variation], in any case, has not renounced its rights: the new form, gathering together the elements of ornamentation and decoration, creates the new Amplifying Variation, which seems to accumulate all the musical forces of variation, of development, and of cyclical transformation. This new avatar of variation, which has killed off the varied Air, might well succeed in bringing about a profound reform in the forms of our art" (d'Indy 1909, 465; emphasis and translation my own; there is no published English translation). 
While d'Indy and Dutilleux were not a direct influence on Tremblay, the latter was certainly familiar with the compositional and theoretical work of Brahms and Schoenberg. Tremblay's former student Alain Lalonde, in an interview with Danick Trottier, stated that the techniques of harmonic analysis Tremblay taught his students were based on Schoenberg's Theory of Harmony (Trottier 2010, 82-3), while Tremblay himself identified that "Brahms thinks more in continuity" (Cornfield 2003). Furthermore, Tremblay's analysis course covered a wide range of repertoire, from Renaissance to contemporary works, and several students identified explicitly that this included study of the styles, genres, and forms of music by common-practice-era composers Beethoven, Mozart, and Haydn (Trottier 2010, 77). Tremblay (1995c) suggested a connection between memory, evolution (or development), and cyclic structures such as $\mathrm{ABA}$ and rondo forms.

In this article, the notion of developing variation will be expanded. While Schoenberg and other scholars specifically identify variation as the expansion of intervals, expansion of other features such as a specific musical gesture or process can also create variation. Such an approach has its roots in transformational theory, a branch of music analysis first developed by David Lewin. In transformational theory, rather than describing music as a series of events or objects, "one can regard the situation actively, like a singer, player, or composer, thinking: 'I am at s; what characteristic transformation do I perform in order to arrive at t?"' (Lewin 1987, xxxi). An important facet of this approach is the understanding of musical events as gestures, and Lewin suggests, "Passages from Schoenberg, Wagner, Brahms, and Beethoven indicate how suggestive it can be to consider networks of 'intervals' and networks of 'transpositions' (modulations, and so forth) as various aspects of the same basic phenomenon" (xxxi). Repetition and composing-out (that is, duplicating similar gestures at different levels of musical structure) are a fundamental part of recognizing these gestures.

In applying transformational theory to developing variation, a few particular applications will prove useful. Joseph Straus's research on composing-out and near-transformations will provide tools for examining relations between local and larger-scale events (Straus 2003). Contour theory will allow us to describe the shape and direction of a melody and its segments. Research by Robert Morris (1993), Ian Quinn (1997), and Straus (2003) has provided detailed methodology for measuring contour; however, Straus observes, "To make sense of musical contour, we do not need to know the exact notes and intervals; we only need to know which notes are higher and which are lower" (126). Accordingly, I will opt for a less mathematical approach that indicates relative melodic direction with the plus or minus symbols (ascending and descending moves, respectively).

Dmitri Tymoczko's work on transformational spaces $(2009,2011)$ builds on Lewin's definition of transformational spaces, creating a tool for understanding intervals as transformations as well as how conceptual spaces can be built from recurring transformations. These spaces need not correspond to chronological events, but rather present an overview of all the possible moves from 
one musical object to another suggested by recurring gestures within a piece, which "allow[s] us to visualize a wealth of musical possibilities at a glance" $(2011,19)$. As John Roeder describes, "Varied repetition appears as the retracing of similar transformational pathways among different sets of musical objects, and closure is articulated by the complete traversal of a transformational space or subspace" (Roeder 2009, 7). Lastly, my own approach to abstracting a recurring semitone motive into a larger structural transformation suggests a useful analytical approach for similar motivic gestures in Croissant (Lind 2008).

A combination of these methodologies will allow us to analyze variation in an atonal context. While variations of a motive are often readily apparent in tonal music, not only from the basic melodic framework but also as the result of similarities in the underlying harmony, in atonal music even basic changes can be difficult to hear. As Lerdahl observes, transformations that do not retain contour are difficult to aurally identify (Lerdahl 2001, 378). Variation in atonal music can thus be difficult to detect, developing variation even more so since it involves a less literal form of variation focusing on a smaller motive or transformation. Throughout this analysis, the identity of a motive (and as a result the identification of its variation) will be established through the retention of one or more elements between two passages; whereas in tonal music this may involve harmony, rhythm, or pitch, in the atonal context presented here pitch, interval, rhythm, and contour will be the defining features within Croissant.

\section{Croissant: Motive and Transformation}

While Croissant does feature some use of the "en mobile" and "reflexe" styles, the major portion of its musical content is based on non-aleatoric material. Short, repeated motives with recurring intervals and rhythms alternate and contrast with one another and with the "en mobile" and "reflexe" passages. Despite this contrast, it becomes apparent over the course of Croissant that what appear on the surface to be contrasting pitch motives are, in fact, developments of one another; Dutilleux's metamorphosis metaphor is particularly apt as the gradual change in these motives accumulate over the course of the work to produce an "essential change" in their nature. The opening motive of the work (figure 3) provides a good reference point for observing this.

This opening motive consists of a short, unison melody featuring a repeated minor-third gesture, separated by rests (note that this minor third will henceforth be represented as a transposition, labelled $\mathrm{T}_{3}$ in its ascending form and $\mathrm{T}_{9}$ in its descending or inverse form, in order to indicate the displacement from the first to the second pitch). Three different pitch-class dyads repeat this transposition: $\langle\mathrm{E}, \mathrm{G}\rangle,\langle\mathrm{C}, \mathrm{A}\rangle$, and $\langle\mathrm{C}$, E $>$. Figure 4 depicts this repetition: while each dyad itself involves a $\mathrm{T}_{3}$ or $\mathrm{T}_{9}$ transposition, the move from the first dyad to the last is also $\mathrm{T}_{9}$. Thus this minor-third motive functions at two levels of structure: both as object (forming the dyad itself) and as transformation (the relation between the dyads). 


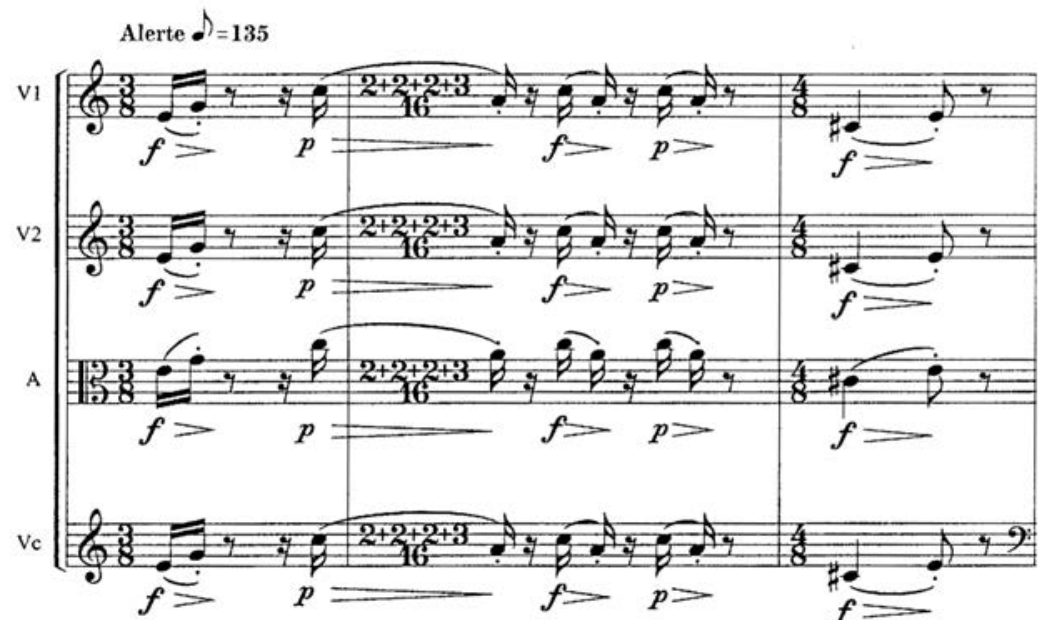

Figure 3. Croissant, opening measures.
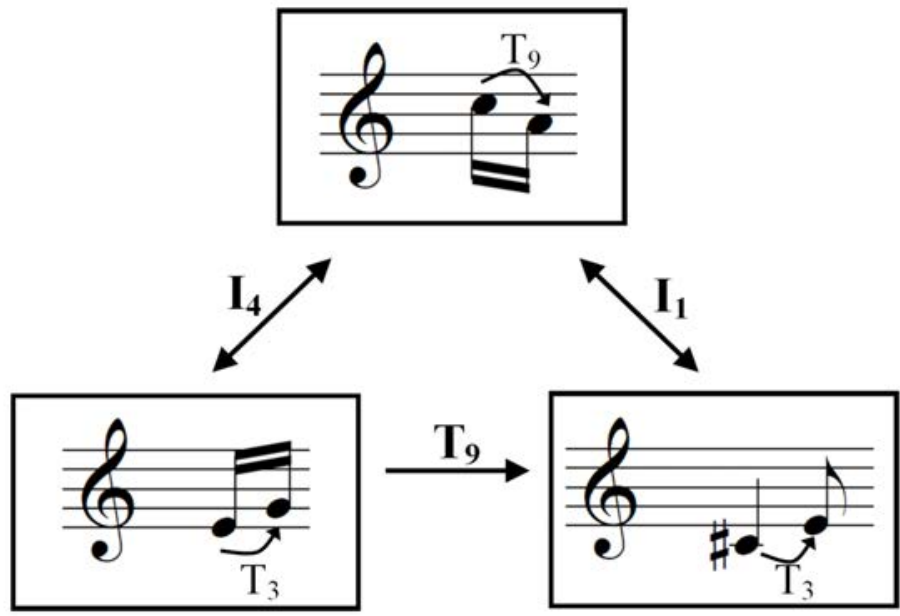

Figure $4: T_{3} / T_{9}$ relationships among the pitches of the opening motive.

The opening motive returns in many forms throughout the work, acting as the seed of development. It first returns at rehearsal 9, given in figure 5, in the same metre and rhythm as the original but no longer in unison.

Pitches from the original motive are highlighted on the figure: these occur from the downbeat of rehearsal 9, but also duplicate in the violin 1 (fifth bar after rehearsal 9), preceded by a new $\mathrm{T}_{9}$ dyad, $\left\langle\mathrm{E}^{b}, \mathrm{C}\right\rangle$. Our previous network can be expanded to create a transformational space representing the repetition of $\mathrm{T}_{3}$ and $\mathrm{T}_{9}$ (figure 6): while the new $<\mathrm{E}^{b}, \mathrm{C}>$ dyad does not relate by $\mathrm{T}_{3}$ or $\mathrm{T}_{9}$ to the first dyad of our original motive, it does generate the second dyad of our original motive via $T_{9}$. Note that the transformational spaces such as these do not necessarily show temporal alignment, but rather depict repeated 


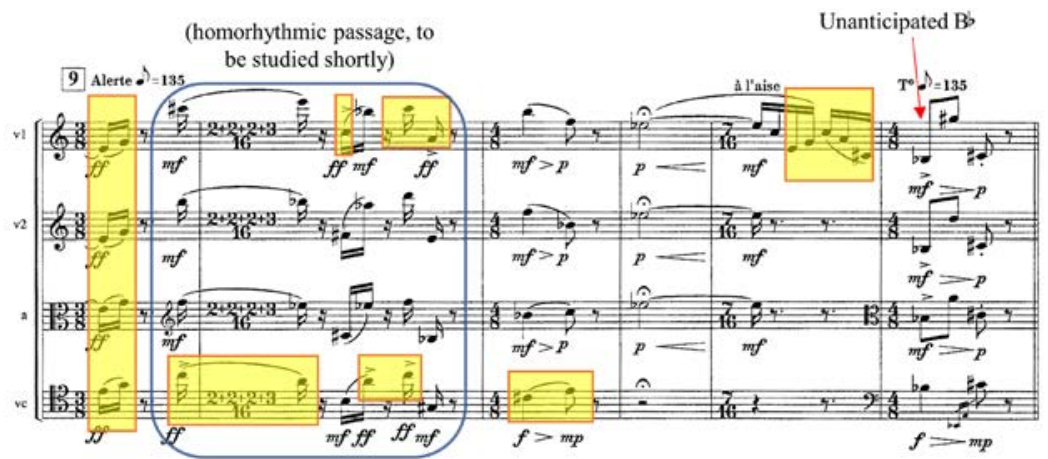

Figure 5: Rehearsal 9.

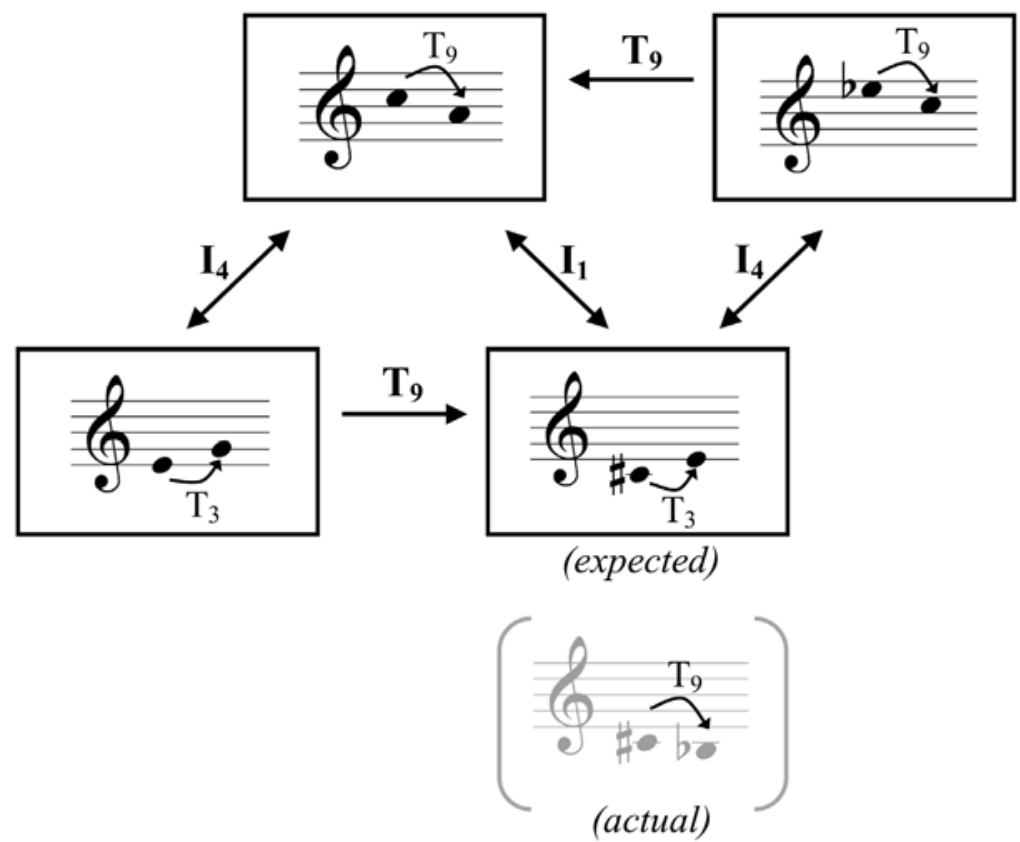

Figure 6. A transformational space modelling rehearsal 9, second half (note that the $<\mathrm{C}$, E $>$ dyad is not realized in the music; the $C \sharp$ proceeds to $B^{b}$ instead. The original dyad is included here for comparison with figure 2).

transformations that underlie the structure of the work. In this case, the figure gives us a network of possible moves based on gestures established thus far in the work, $\mathrm{T}_{9}, \mathrm{I}_{1}$, and $\mathrm{I}_{4}$. This allows us to define our musical expectations and then discuss how the actual music thwarts its realization. For example, if this passage were to correspond to our original motive, the melody would proceed by $\mathrm{T}_{3}$ from $\mathrm{C} \sharp$ to $\mathrm{E}$; instead, it moves by $\mathrm{T}_{9}$, reversing the direction of the interval to arrive at $\mathrm{Bb}$. This disruption of the expected melodic continuation creates a small variation in the structure of the melody. Furthermore, in this 
passage variation also occurs with the introduction of new pitches to accompany the restatement of the melody at rehearsal 18.

In developing variation, motivic change and development need not refer back to the original theme, but rather may be sourced from one of the preceding variations. In Croissant, two variations derived from rehearsal 9 illustrate this concept well. As seen in rehearsals 16-18 (figure 7 ), the $\mathrm{T}_{3} / \mathrm{T}_{9}$ motive from the original theme occurs towards the end of the section in the cello and violin 1. However, this is not immediately apparent, given that the statement occurs in retrograde; it is the repetition of the $\mathrm{T}_{9}$ dyad, and not the ordered six-note series, that suggests this motive might relate to the opening theme. The chords that occur in conjunction with this retrograde melody (shown with a blue oval in each passage) are also in retrograde from rehearsal 9. Figure 8 compares the chord progressions from rehearsals 9 and 17: pitch/register are (mostly) consistent between the two passages, while the chord order is retrograded. Dashed lines represent semitone displacements to notes in three chords, which add a new element of variation.

While the opening motive is still identifiable at rehearsal 17 , enough change has been introduced to suggest a new motivic identity. The rhythm is changed, with a new .0 motive established through repetition, and dyad repetition on
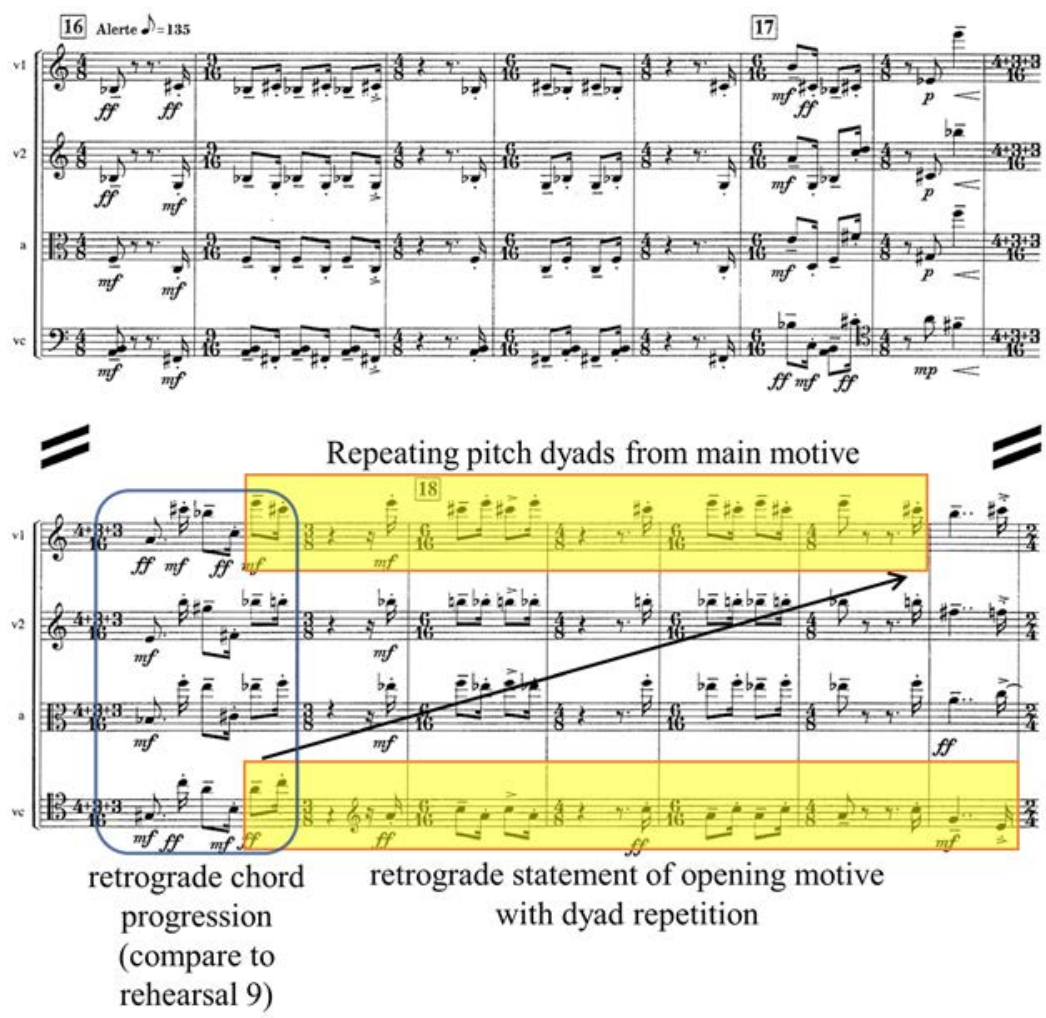

Figure 7. Rehearsals 16-18. 


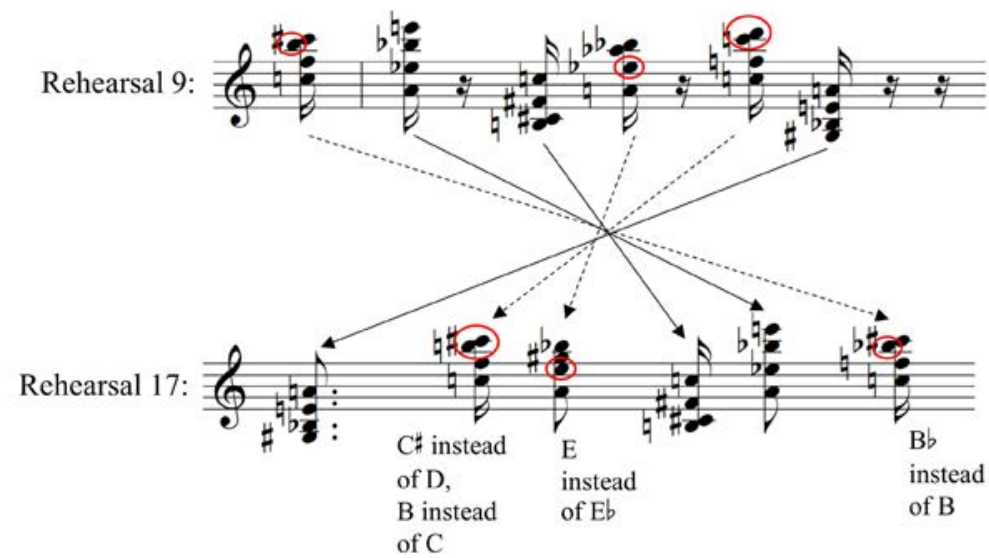

Figure 8. Comparing chords from rehearsal 9 to rehearsal 17. Solid arrows indicate identical chords, while broken arrows indicate chord pairs with one-semitone pitch displacements.

new pitch classes occurs in all voices. It is these two features, and not the original six-note pitch series, that are most aurally salient in this passage; the music has undergone enough change to establish a new musical identity.

A second instance at rehearsal 31 demonstrates a similar establishment of motivic identity. As highlighted on figure 9, the music once again embeds the opening motive in the lowest voice; the adherence to the motive's original pitch level, its retained contour, and the fragmentation and repetition of the $T_{3} / T_{9}$ dyads makes its identity clear. Like rehearsal 16-18, it features homorhythm in alternating meters and a return of the.$\$$ rhythm. It also includes short passages that mimic rehearsal 16: the fourth measure of rehearsal 31, for example, contains the same pitches as rehearsal 18, but with the rhythm exchanged (long-short instead of short-long). There is thus a clear relationship between rehearsals $16-18$ and 31. However, the two passages are not identical: a new level of variation is once again added. Rehearsal 31 clearly features new pitch material in the three upper strings, as well as a four- or five-sixteenth note rhythm not previously emphasized (heard in measures 1,3 , and 5 of rehearsal 31 ).

In addition, the music at rehearsal 31 is rigidly structured through a specific inversional process. For the sake of clarity, the pitch classes of the first four chords of rehearsal 31 are given in Figure 10, in the same visual orientation as the score (left-to-right chronological ordering and top-to-bottom registral/ instrumental ordering). As can be seen by the diagram, the chords feature a registral exchange often characteristic of pitch inversion, where the highest voice inverts onto the lowest, and vice-versa. The particular inversion is $I_{8}$, an inversion representing an axis of symmetry of $\mathrm{E}_{4}$, with each note of the inversional pair an equal distance away from this pitch (shown on figure 11).

This particular inversion has not been prominent up to this point in the work. However, at rehearsal 31 it is an essential component in generating the complete four-voice structure: chord pairs related by $\mathrm{I}_{8}$ occur several times within the passage, as shown with boxes on figure 12. For example, bar 2 compresses 


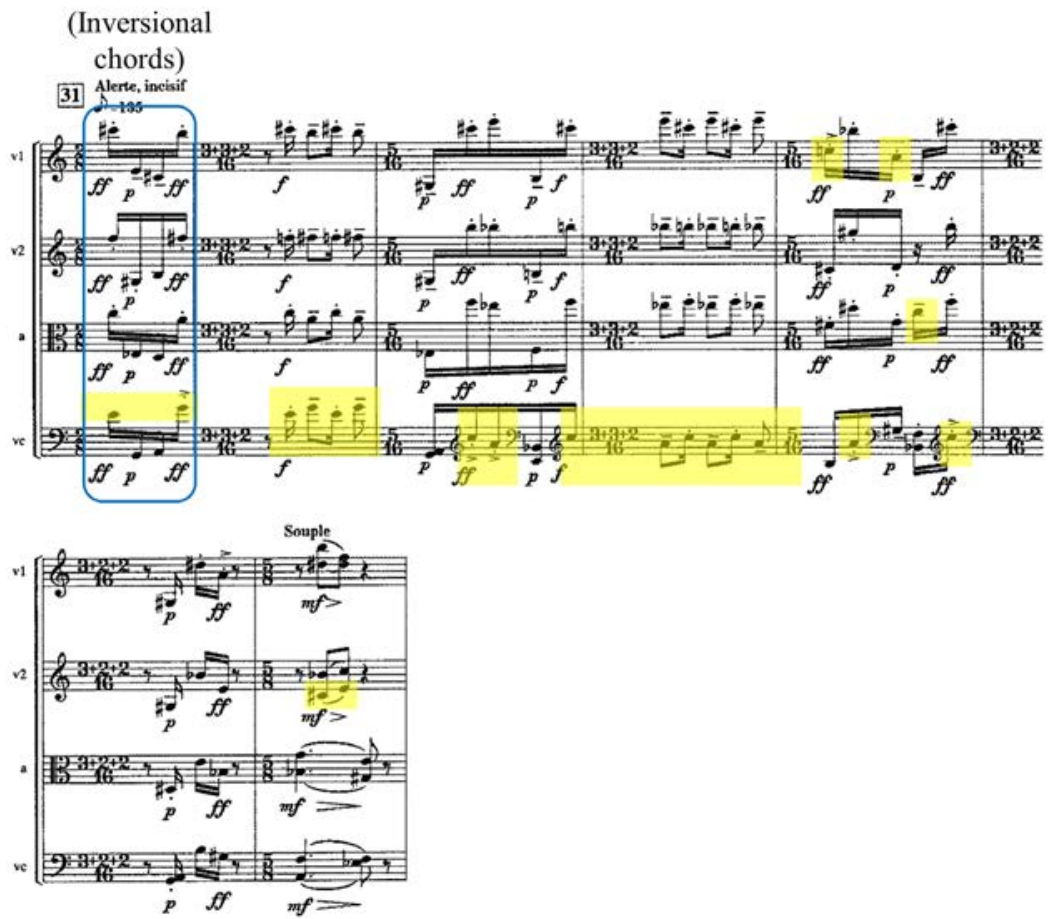

Figure 9. Rehearsal 31 (reiterations of opening motive's pitch classes shaded for reference).

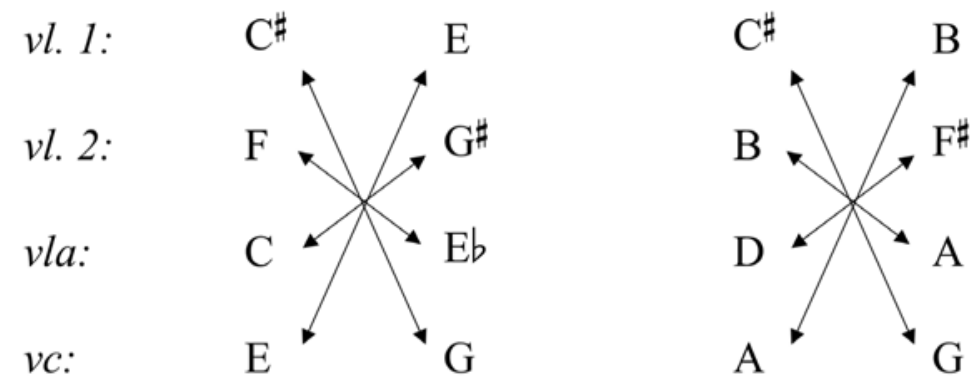

Figure 10. Opening chords of rehearsal 31 and their inversional relationships (arrows indicate pitch classes related by $\mathrm{I}_{8}$ )

the progression from bar 1 , and similarly, bar 4 compresses the progression of bar 3 . The fourth- and third-last chords are "near" I: if o (C) were substituted for the 3 in the first violin, this would form another $I_{8}$ complex. The only materials not involved in $\mathrm{I}_{8}$ structuring are in bar 5: the first two chords form an I9 relation with one another, while the second two relate by $\mathrm{I}_{7}$.

If we compare this music to passages later in the work, there is a clear retention of process rather than pitch: $\mathrm{I}_{8}$ acts as a structuring transformation. See, for example, the music of rehearsal 33 and rehearsal 35, given in figures 13 and 


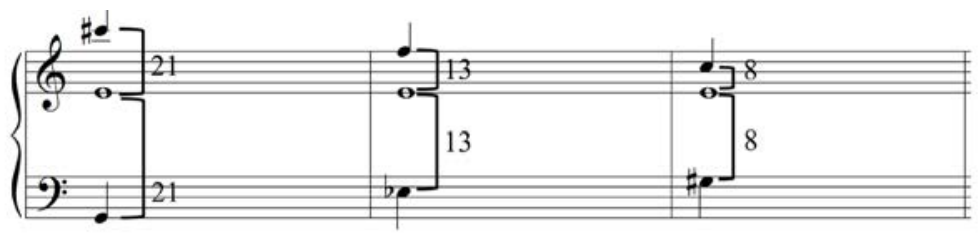

Figure 11. $\mathrm{E}_{4}$ as inversional axis, with distance in semitones from $\mathrm{E}_{4}$ for all other pitches.

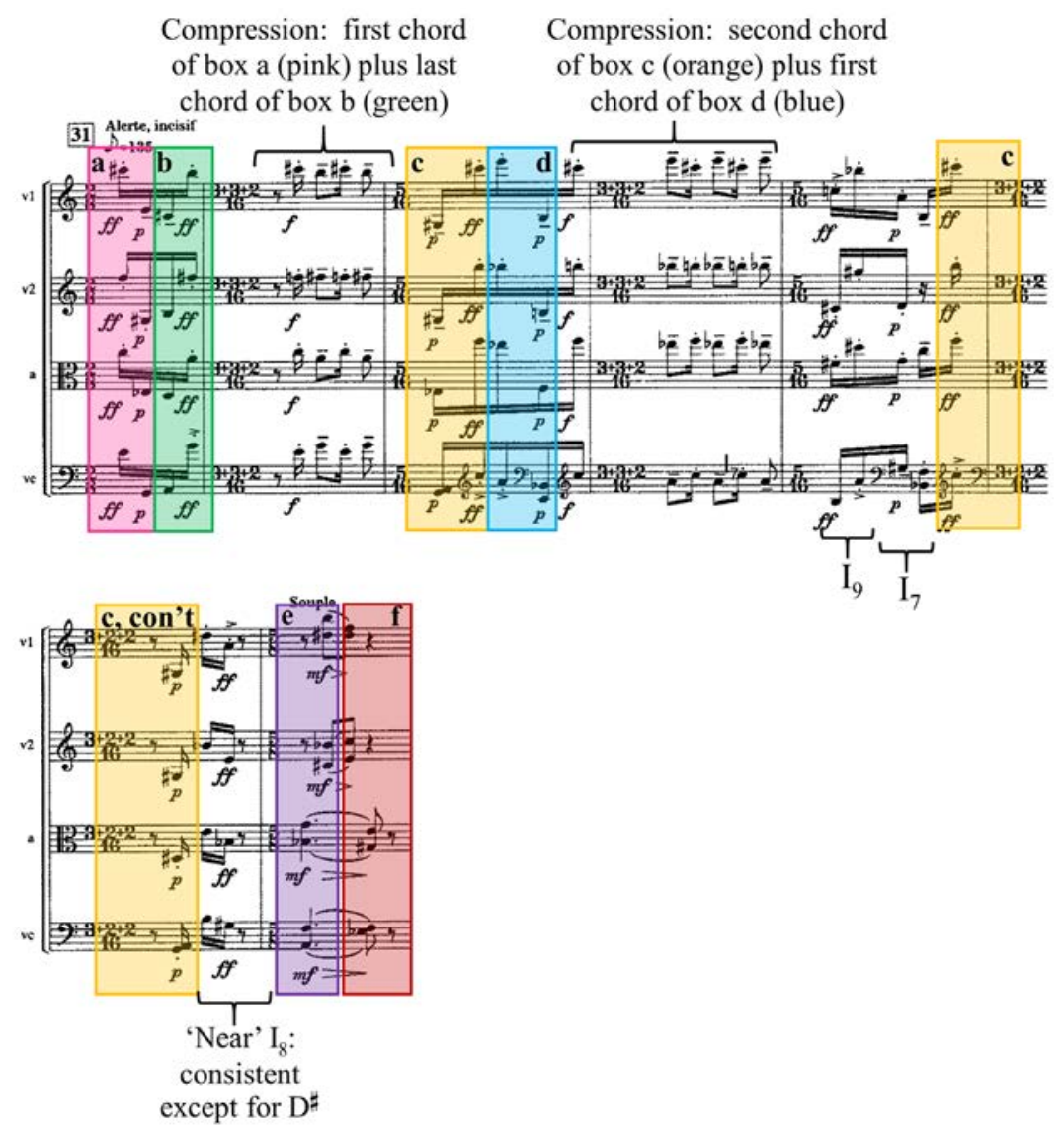

Figure 12. Inversion by $I_{8}$ at rehearsal 31 .

14, respectively. Rehearsal 33 duplicates the pitches of rehearsal 31 but recasts them in a new rhythm and metre. Rehearsal 35, on the other hand, contains an entirely new collection of pitches, but surprisingly still sounds related to rehearsal 33. Why so? As shown in figure 15, while the rhythm of rehearsal 35 is neither identical nor proportional to the original, agogic accents (boxed on the figure) and tenuto markings occur in analogous locations, with the former on the second, fourth, sixth, and eighth notes of both passages and the latter on the second, sixth, and eighth notes. 

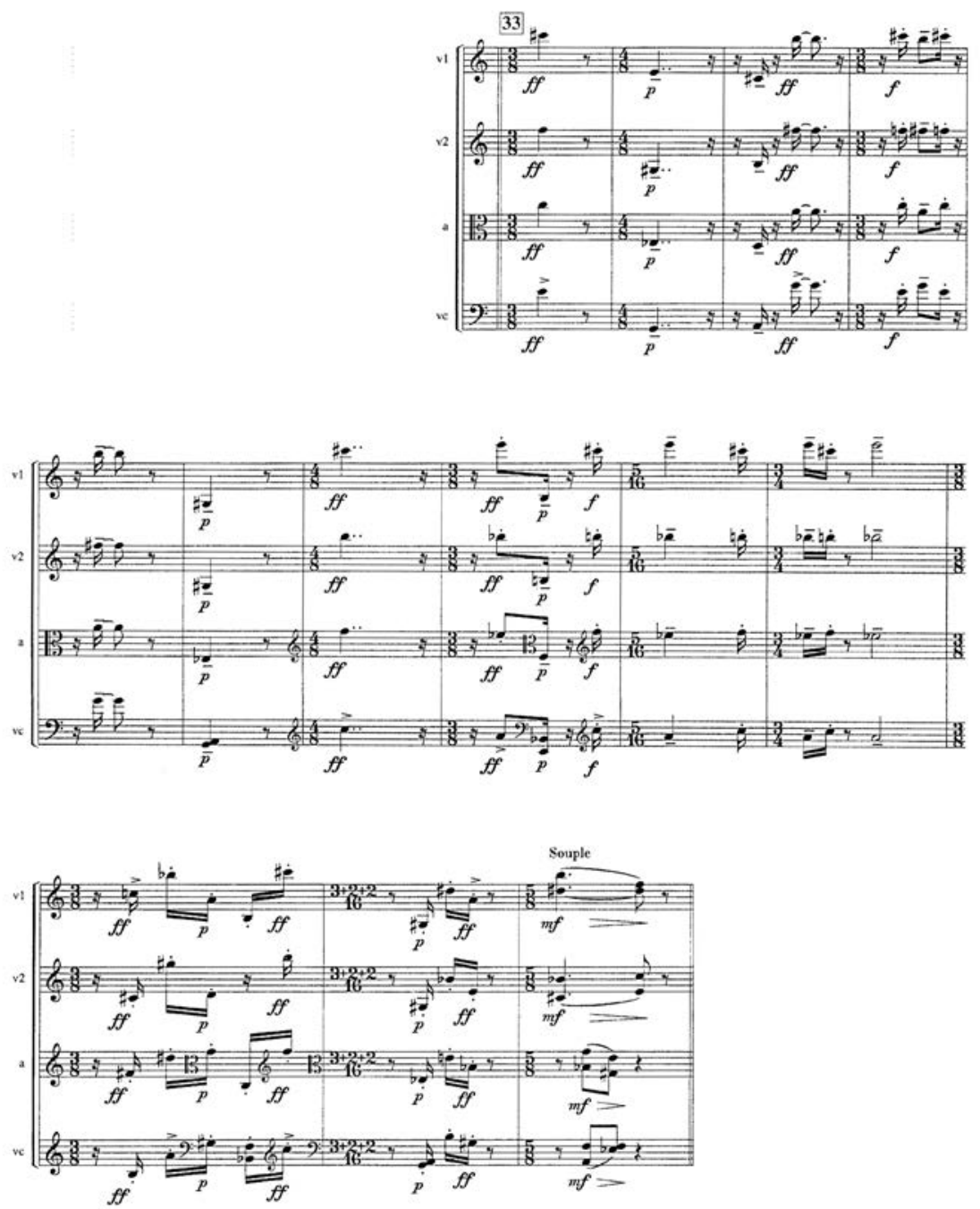

Figure 13. Rehearsal 33.

Second, there are clear similarities in contour between the two passages. Figure 16 combines the pitches of rehearsals 33 and 35 into one system, eliminating rhythmic values, metre, and articulations. As can be seen on the figure, the direction of each voice remains the same between rehearsal 33 and 35 until approximately two-thirds of the way through the passage (interval size is also similar, although this has not been indicated on the figure).

Last, while the pitch classes of rehearsal 35 are new, their relationship to one another is not: as shown in figure $17, \mathrm{I}_{8}$ once again structures pairs of chords within the passage, and there are also similar repetitions, compressions, and deviations from $\mathrm{I}_{8}$-structuring in analogous locations. The prominence of $\mathrm{I}_{8}$ structure suggests we might want to reconsider our definition of motive in 

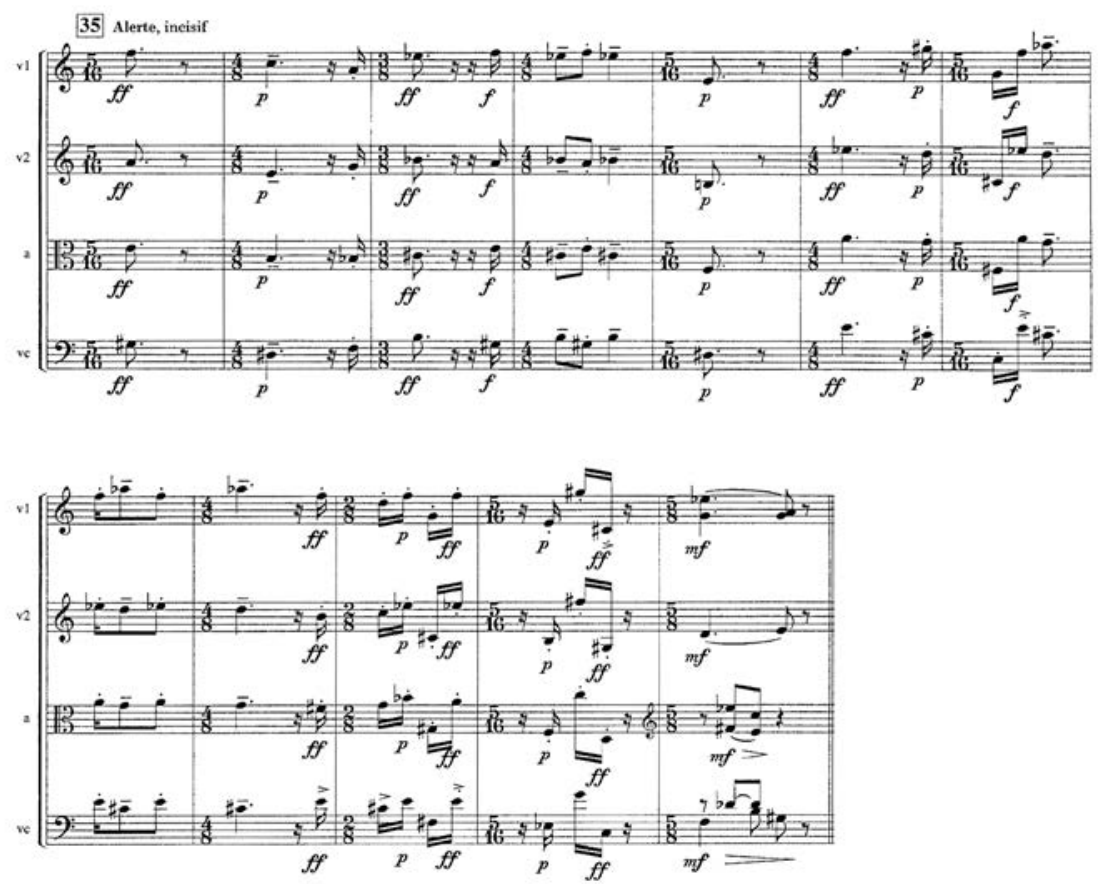

Figure 14. Rehearsal 35 .

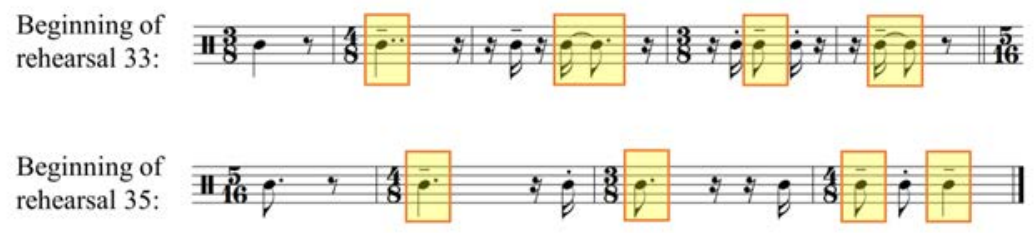

Figure 15. Agogic accents (boxed) in rehearsals 33 and 35.

Croissant: from the perspective of transformational theory, rather than asking, "What pitches does the motive contain?" we might better be served by asking, "What action does this motive do?" The motive has been abstracted from a set of fixed pitches to a specific relationship between pitches and other musical objects. The retention of this element through reiterations of A suggests we want to retain that label, but the music is no longer recognizably similar to the music of the opening measures. As such, we will call this newly transformed motive A2.

\section{IDENTITY}

We have seen that motive forms in Croissant consists of musical objects such as the recurring pitch melody $<\mathrm{E}, \mathrm{G}, \mathrm{C}, \mathrm{A}, \mathrm{C} \#, \mathrm{E}>$, but also of musical processes such as $\mathrm{I}_{8}$. In each case, one or more parameters from a previous motivic statement are retained, but at least one new feature that uniquely defines a new 


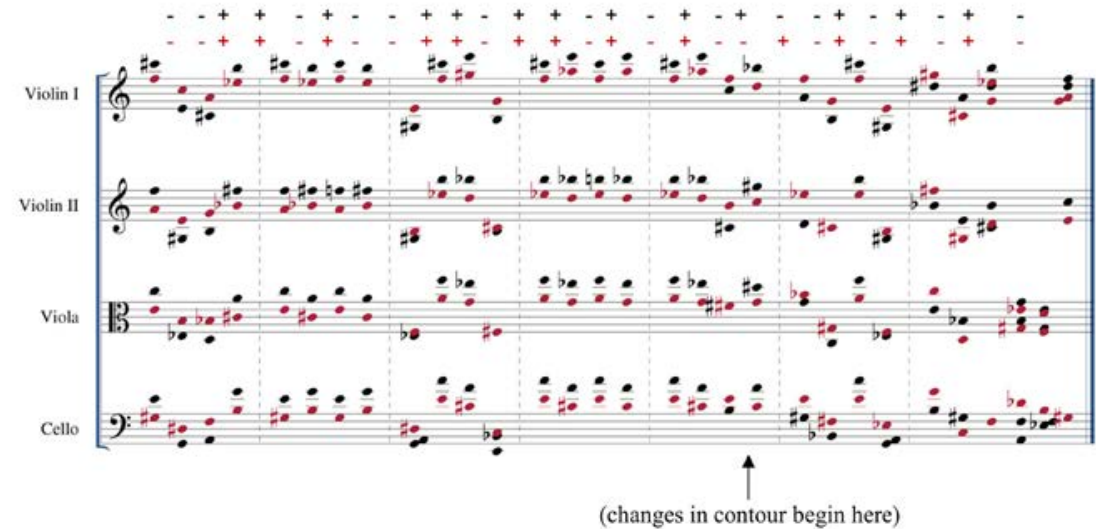

Figure 16. Pitches of rehearsals 33 (black) and 35 (red), merged into one system. Note that dashed "bar lines" are included only for the reader's convenience to separate out groups of four chords and do not correspond to bar lines in the actual music.
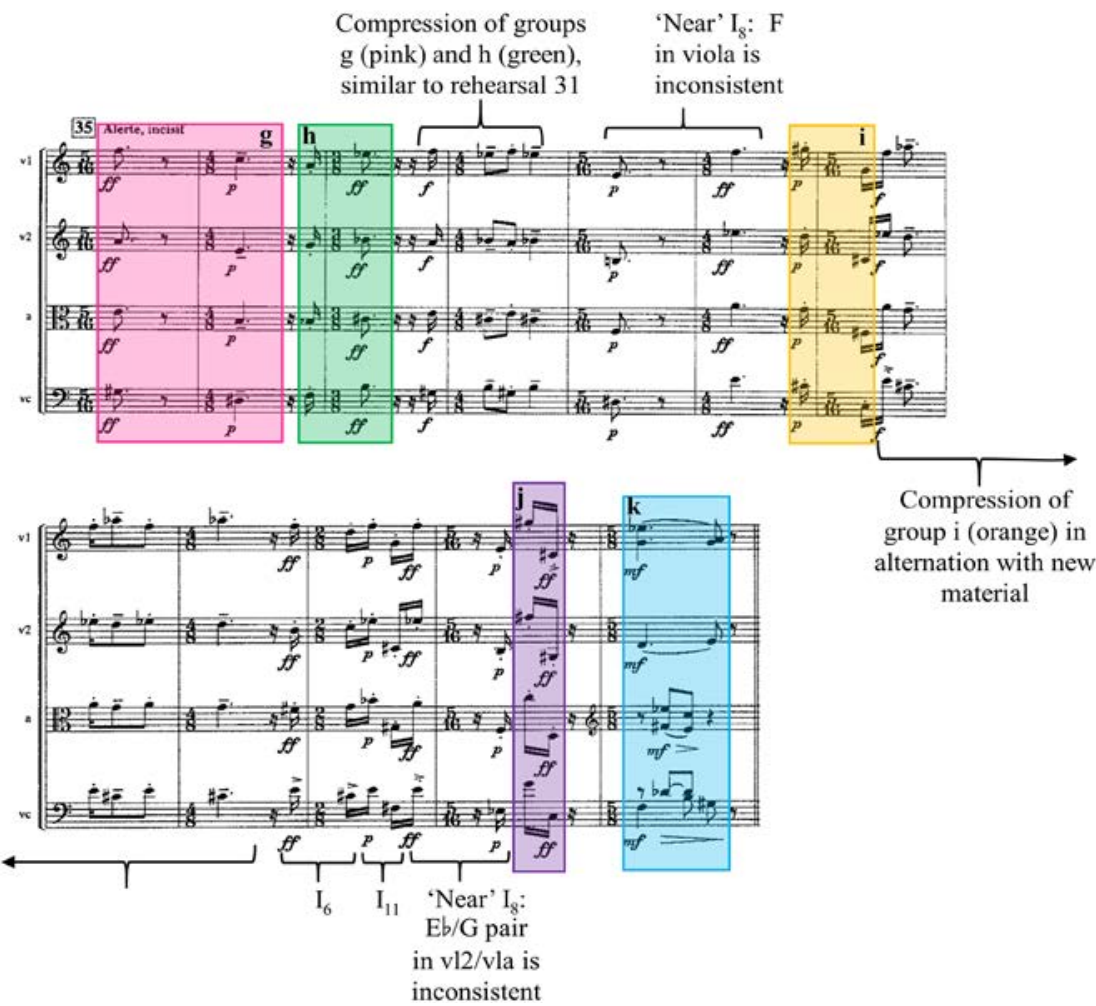

Compression of group i (orange) in alternation with new material

Figure 17. $\mathrm{I}_{8}$ relationships at rehearsal 35 . 
motive form is introduced. This results in gradual change over time, since variation is based not just on the original motive, but also on later motive forms. We have examined instances of $\mathrm{A}_{1}$ and $\mathrm{A}_{2}$ already; by the end of the work, five different motive forms of the A material occur, as summarized in table 1. As can be seen in the table, in each case there is at least one identity-generating element retained from the previous motive-form, and at least one new feature added.

Table 1. Establishing identity within motive groups.

\begin{tabular}{|c|c|c|c|c|c|}
\hline $\begin{array}{l}\text { Motive } \\
\text { group }\end{array}$ & $\mathrm{A} 1$ & A2 & A3 & A4 & A5 \\
\hline \multirow[t]{5}{*}{ Identity } & $\begin{array}{l}<E-G-C-A- \\
C \#-E>\end{array}$ & $\begin{array}{l}<E^{b}-C-E-G-C- \\
A-C \#>\end{array}$ & I8 structure & $\begin{array}{l}\text { "Jubilus" } \\
\text { marking }\end{array}$ & $\begin{array}{l}\text { Arpeggio } \\
\text { fragments in } \\
\text { 32nd-durations }\end{array}$ \\
\hline & $\mathrm{T}_{3} / \mathrm{T}_{9}$ dyads & $\mathrm{T}_{3} / \mathrm{T}_{9}$ & $\begin{array}{l}\text { Repeated } .0 \\
\text { rhythm }\end{array}$ & $\begin{array}{l}\text { Arpeggio } \\
\text { melody in } \\
32 \text { nd-durations }\end{array}$ & I8 structure \\
\hline & $\begin{array}{l}\text { Dyad } \\
\text { repetition }\end{array}$ & $\begin{array}{l}\text { Dyad } \\
\text { repetition }\end{array}$ & Homorhythm & $\begin{array}{l}\text { Quarter- } \\
\text { duration ac- } \\
\text { companiment }\end{array}$ & \\
\hline & & I8 structure & $\begin{array}{l}\text { Contour } \\
\text { (see fig. 16) }\end{array}$ & $\begin{array}{l}T_{3} / T_{9} \text { in } \\
\text { accompani- } \\
\text { ment voices } \\
\text { suggesting } \\
\text { hidden }<E, G \text {, } \\
C, A, C \#, E> \\
\text { motive }\end{array}$ & \\
\hline & & $\begin{array}{l}\text { Repeated } .0 \\
\text { rhythm }\end{array}$ & & & \\
\hline
\end{tabular}

In most cases each individual has one "parent" form; however, in some cases an earlier motive form returns to influence a newer one. For example, while the music of rehearsal 50 is generated primarily from the music of rehearsal 32 (figure 19), sharing its rhythm and texture of thirty-second-note melody with chordal accompaniment (and thus belonging to the A4 motive form), a less audible link to the opening motive also occurs in the viola, which states the original pitch motive, $<\mathrm{E}, \mathrm{G}, \mathrm{C}, \mathrm{A}, \mathrm{C} \sharp>$ minus the concluding pitch E. Looking back at rehearsal 32, the same melody occurred in inversion in the violin 2, once again at $\mathrm{I}_{8}$. Neither of these two inner-voice pitch motives is likely to be identified as the main feature of this melody, given the active rhythm in the violin and cello lines as well as the homorhythmic accompaniment, but nonetheless they suggest an economy of motivic material characteristic of variation.

In Croissant, the generation of new motive forms sometimes occurs in unexpected ways. For example, the shift to motive-form A5 occurs at rehearsal 39 (figure 20). If we were to compare this music with the opening motive, it would be difficult to see that rehearsal 39 relates to the opening motive at all: in the later passage, $T_{3} / T_{9}$ is not prominent, the original pitch motive is not heard, and there are no obvious rhythmic, metric, or textural similarities to 


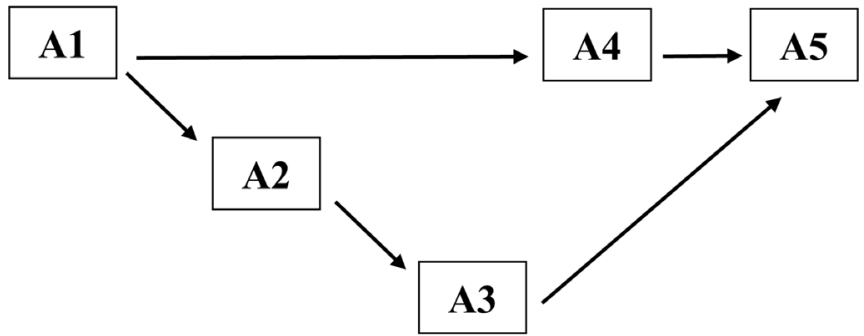

Figure 18. Progression between motive forms.

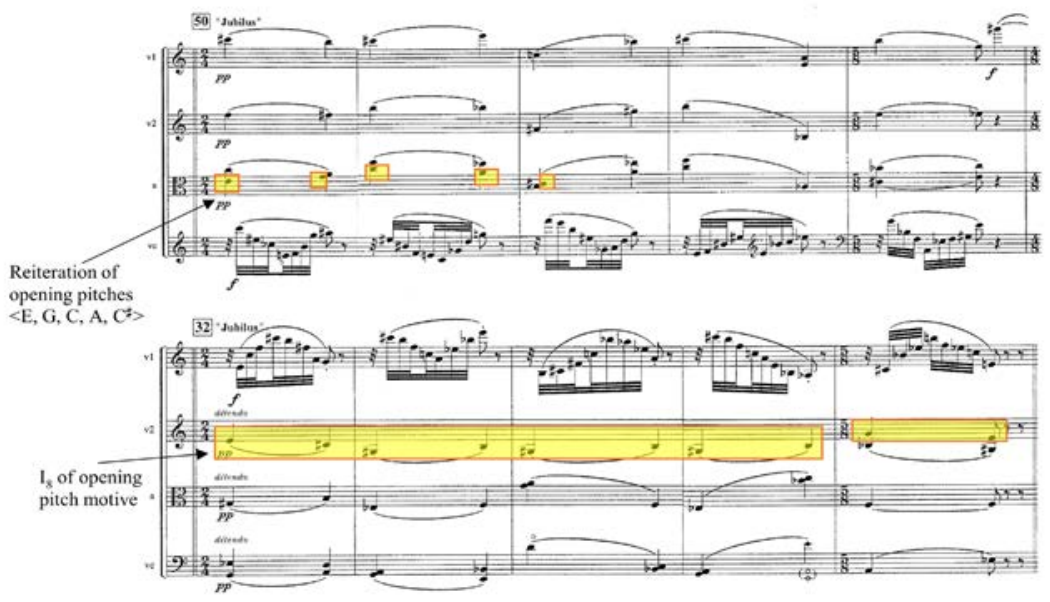

Figure 19. Comparing rehearsal 50 with rehearsal 32.

the earlier music. However, there are very strong similarities to the $\mathrm{A}_{4}$ branch of the family tree just examined in figure 19, since the new passage shares the rhythm and arpeggiation style of A4. There are also similarities to the A2 and $\mathrm{A}_{3}$ branches (previously examined in figures 9, 12, and 17), since this music continues the $\mathrm{I}_{8}$ structuring established therein, this time with four-note melodic motives instead of chords (shown with arrows on figure 20). This particular variation group has thus been generated through the synthesis of two previous processes. This is not typical of straight variation, but is not unusual for developing variation.

\section{IMPLICATIONS FOR LARGE-SCALE FORM}

A shift of parameter can help to define large-scale form within the work. Table 2 summarizes the presentation of motivic material over the course of the entire work, with motive forms A1-A5 coloured to highlight their appearance. A summary of other motivic groups is also given on the table 2: six other types 

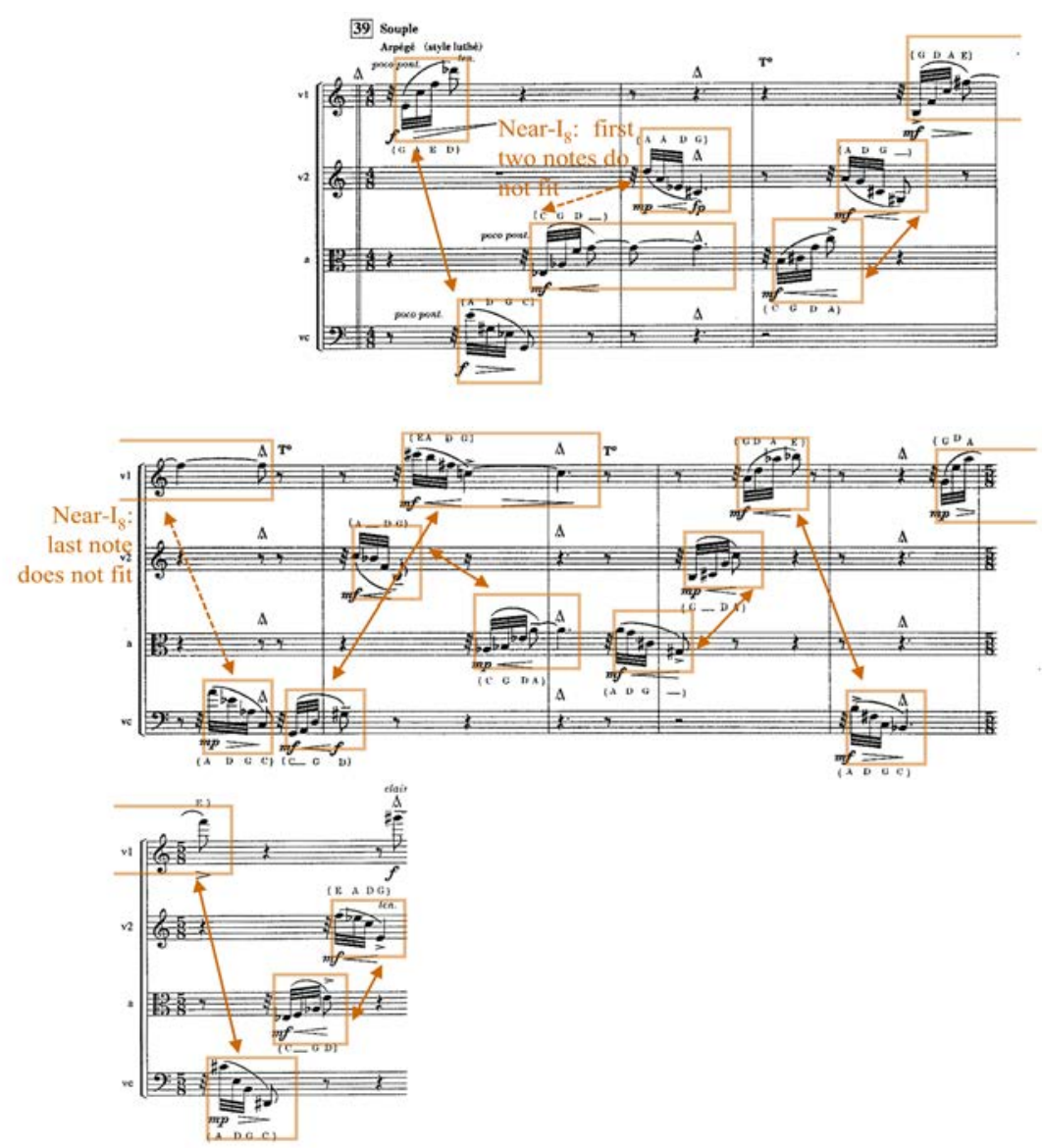

Figure 20. Rehearsal 39 (arrows indicate I8 relationships).

of material appear, each of which is given a short stylistic description on the table.

Looking at the overall process, while there is a divergence from the opening motive for much of the work, at rehearsal 69 there is a return to an earlier style, combining the characteristic parameters of several A motive forms. This suggests a cyclic structure.

As can be seen on figure 21, A1 material returns as the pitch-motive of the opening six-note series in the first two measures, fragmentation derived from the $A_{2}$ and $A_{3}$ families occurs in rehearsals 72 through 76 , and the contour of the $A_{1}$ and $A_{2}$ families recurs. While Tremblay may not be explicitly attempting to mimic traditional rounded forms, his process is surprisingly consistent with Schoenberg's approach to variation. As Haimo observes, "Although it is difficult to generalise, Schoenberg usually generates new material in those two dimensions only through the first third to a half of a formal entity (movement, prelude, scene, etc.). After that point, he normally returns to material already produced, by taking the ideas that have been generated and subjecting them to 
Table 2. Summary of motivic content over the course of Croissant.

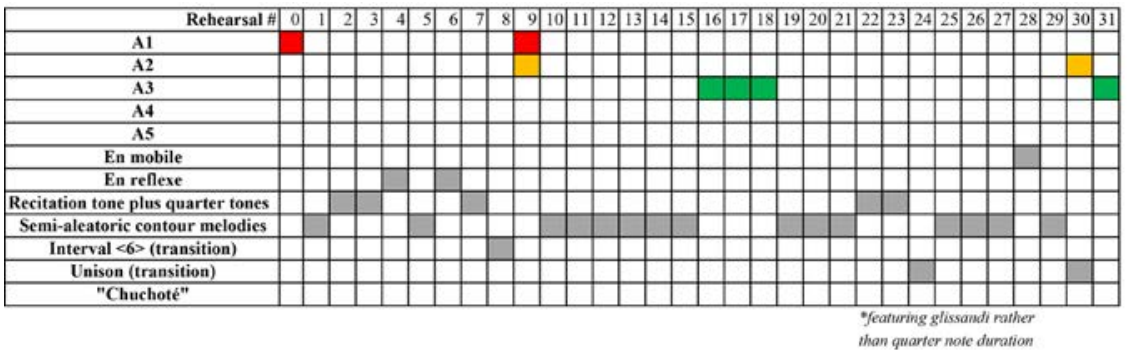

\begin{tabular}{|c|c|c|c|c|c|c|c|c|c|c|c|c|c|c|c|c|c|c|c|c|c|c|}
\hline Rehearsal \# & 32 & \begin{tabular}{|l|l|l}
33 & 3 \\
\end{tabular} & \begin{tabular}{l|l|l}
34 & 35 \\
\end{tabular} & 536 & 373 & $38 \sqrt{3}$ & \begin{tabular}{l|l|l|l|}
39 & 40 & 4 \\
\end{tabular} & \begin{tabular}{|l|l|l|}
41 & 4 \\
\end{tabular} & \begin{tabular}{l|l|l|}
42 & 43 & 4 \\
\end{tabular} & \begin{tabular}{l|l|l|}
44 & 45 \\
\end{tabular} & \begin{tabular}{|l|l|l|}
5 & 46 \\
\end{tabular} & \begin{tabular}{|l|l|}
47 & 48 \\
\end{tabular} & \begin{tabular}{|l|l|l|}
8 & 59 & 50 \\
\end{tabular} & \begin{tabular}{l|l|l|}
0 & 51 & 52 \\
\end{tabular} & 253 . & \begin{tabular}{|l|l|}
54 & 55 \\
\end{tabular} & 56 & \begin{tabular}{|l|l|l}
57 & 58 \\
\end{tabular} & \begin{tabular}{l|l|l|}
88 & 59 \\
\end{tabular} & 606 & \begin{tabular}{l|l}
61 & 62 \\
\end{tabular} & \begin{tabular}{|l|l|}
2 & 63 \\
\end{tabular} \\
\hline A1 & & & & & & & & & & & & & & & & & & & & & & \\
\hline A2 & & & & & & & & & & & & & & & & & & & & & & \\
\hline $\mathbf{A 3}$ & & & & & & & & & & & & & & & & & & & & & & \\
\hline A4 & & & & & & & & & & & & & & & & & & & & & & \\
\hline A5 & & & & & & & & & & & & & & & & & & & & & & \\
\hline En mobile & & & & & & & & & & & & & & & & & & & & & & \\
\hline En reflexe & & & & & & & & & & & & & & & & & & & & & & \\
\hline Recitation tone plus quarter tones & & & & & & & & & & & & & & & & & & & & & & \\
\hline Semi-aleatoric contour melodies & & & & & & & & & & & & & & & & & & & & & & \\
\hline Interval $<6>$ (transition) & & & & & & & & & & & & & & & & & & & & & & \\
\hline Unison (transition) & & & & & & & & & & & & & & & & & & & & & & \\
\hline "Chuchote" & & & & & & & & & & & & & & & & & & & & & & \\
\hline
\end{tabular}

\begin{tabular}{|c|c|c|c|c|c|c|c|c|c|c|c|c|c|c|c|c|c|c|c|c|c|c|c|c|}
\hline Rehearsal $\mathrm{H}$ & 64 & 656 & 666 & \begin{tabular}{l|l}
67 & 6 \\
\end{tabular} & \begin{tabular}{l|l}
68 & 6 \\
\end{tabular} & \begin{tabular}{l|l|l|}
69 & 70 & 7 \\
\end{tabular} & \begin{tabular}{|l|l|}
71 & 72 \\
\end{tabular} & 7273 & 7445 & \begin{tabular}{l|l|l|}
75 & 76 & \\
\end{tabular} & 777 & 787 & 79 & \begin{tabular}{l|l}
80 & 8 \\
\end{tabular} & \begin{tabular}{l|l}
81 & 8 \\
\end{tabular} & \begin{tabular}{l|l}
82 & 8 \\
\end{tabular} & 838 & \begin{tabular}{l|l|}
84 & 85 \\
\end{tabular} & 86 & 878 & \begin{tabular}{l|l}
88 & 8 \\
\end{tabular} & 899 & \begin{tabular}{l|l|l}
90 & 91 \\
\end{tabular} & 92 \\
\hline A1 & & & & & & & & & & & & & & & & & & & & & & & & \\
\hline A2 & & & & & & & & & & & & & & & & & & & & & & & & \\
\hline A3 & & & & & & & & & & & & & & & & & & & & & & & & \\
\hline A4 & & & & & & & & & & & & & & & & & & & & & & & & \\
\hline A5 & & & & & & & & & & & & & & & & & & & & & & & & \\
\hline En mobile & & & & & & & & & & & & & & & & & & & & & & & & \\
\hline $\begin{array}{c}\text { En reflexe } \\
\end{array}$ & & & & & & & & & & & & & & & & & & & & & & & & \\
\hline Recitation tone plus quarter tones & & & & & & & & & & & & & & & & & & & & & & & & \\
\hline Semi-aleatoric contour melodies & & & & & & & & & & & & & & & & & & & & & & & & \\
\hline Interval $<6>$ (transition) & & & & & & & & & & & & & & & & & & & & & & & & \\
\hline Unison (transition) & & & & & & & & & & & & & & & & & & & & & & & & \\
\hline "Chuchoté" & & & & & & & & & & & & & & & & & & & & & & & & \\
\hline
\end{tabular}

further variation, but without transforming them so completely that they lose their identity" (Haimo 1997, 362)

Haimo's description of Schoenberg's compositional process, in fact, is an apt description of the overall formal process in Croissant:

Schoenberg employs different techniques of developing variation in different circumstances. At the beginning of a formal unit, the theme unfolds by a process of developing variation that progressively yields new and contrasting ideas [observed from the beginning to rehearsal 52 in Croissant]. But once the composition is well under way, such stratagems are neither necessary nor apposite. Instead, Schoenberg reaches back to the material he has already created and recycles it for further use. However, it was not in Schoenberg's makeup to bring anything back unaltered. Therefore, after approximately the first third of a formal unit, he normally restates familiar figures in new combinations and with new alterations, without, however, continually producing dramatically new designs [beginning at rehearsal 69 in Croissant, and arguably the content beginning at rehearsal 
50 that combines the A2 motive form with the recitation tone motive]. This is not to say that developing variation ceases after this point, simply that it takes on a slightly different role and character. (Haimo 1997, 363)

Dutilleux, in his description of variation, argues that such a process may still be representative of recapitulation, in spite of not adhering to the usual classical norms for that process; the listener's memory is triggered by motivic fragments reminiscent of previous material: "If you apply a process of wide-ranging variation to a given formula-whether it's melodic, harmonic or rhythmic - to the point that this formula becomes unrecognizable, can you say there is no recapitulation? The phenomenon of memory attaches itself to this scrap of the formula or to what is left of it after its subtle metamorphoses" (Dutilleux 2003, via Hesketh 2010, 465).

In Croissant, therefore, a cyclic structure, including a suggested recapitulation at rehearsal 69, is accomplished through the restatement of earlier thematic material, and a liquidation and undoing of motivic development, very much in line with the Schoenbergian paradigm.

\section{Conclusion}

"I appreciate the subtle changing from one block to another"

(Gilles Tremblay, via Messier and Messier 2006)

How might this study be expanded further? Certainly the musical content of Croissant beyond the A motive-forms would prove fruitful for such a study; developing variation is already suggested by the blending of A motive-forms with other textural and aleatoric content as identified in table 2. A quick examination of another work by Tremblay suggests that a similar analytical approach may be useful for similar repertoire. In Phases (1955/6), the opening measures establish an inversion centred upon the pitch centre of $\mathrm{D}_{4}, \mathrm{I}_{4}$ (inversional pairs of pitch classes are connected with arrows on figure 22). At measure 30 (shown in figure 23) seemingly new motivic material features a rhythm different from the opening (sixteenths rather than eighth notes). Neither does it repeat the opening $<\mathrm{E}^{b}, \mathrm{C}, \mathrm{E}, \mathrm{C} \sharp>$ motive from measure 1 . However, there is a similarity between the registral distribution of pitches in measures 2-3 and measures 31-2. While this may not be an audible relationship as a result of the now-retrograde ordering of these pitches, the similar registral distribution is due to a repetition of the $\mathrm{I}_{4}$ inversion established at the beginning of the work. This, coupled with a return to a slower tempo, suggest a return of the A section.

Developing variation provides an interesting link to the title of Croissant, which translates to "growing" in English: Tremblay is intimately concerned with processes of generating new content that maintain the idea of growth, not only of motive but also of the larger ideological process. New ideas develop from old, with each generation (in both senses of the word) highlighting new musical properties. 

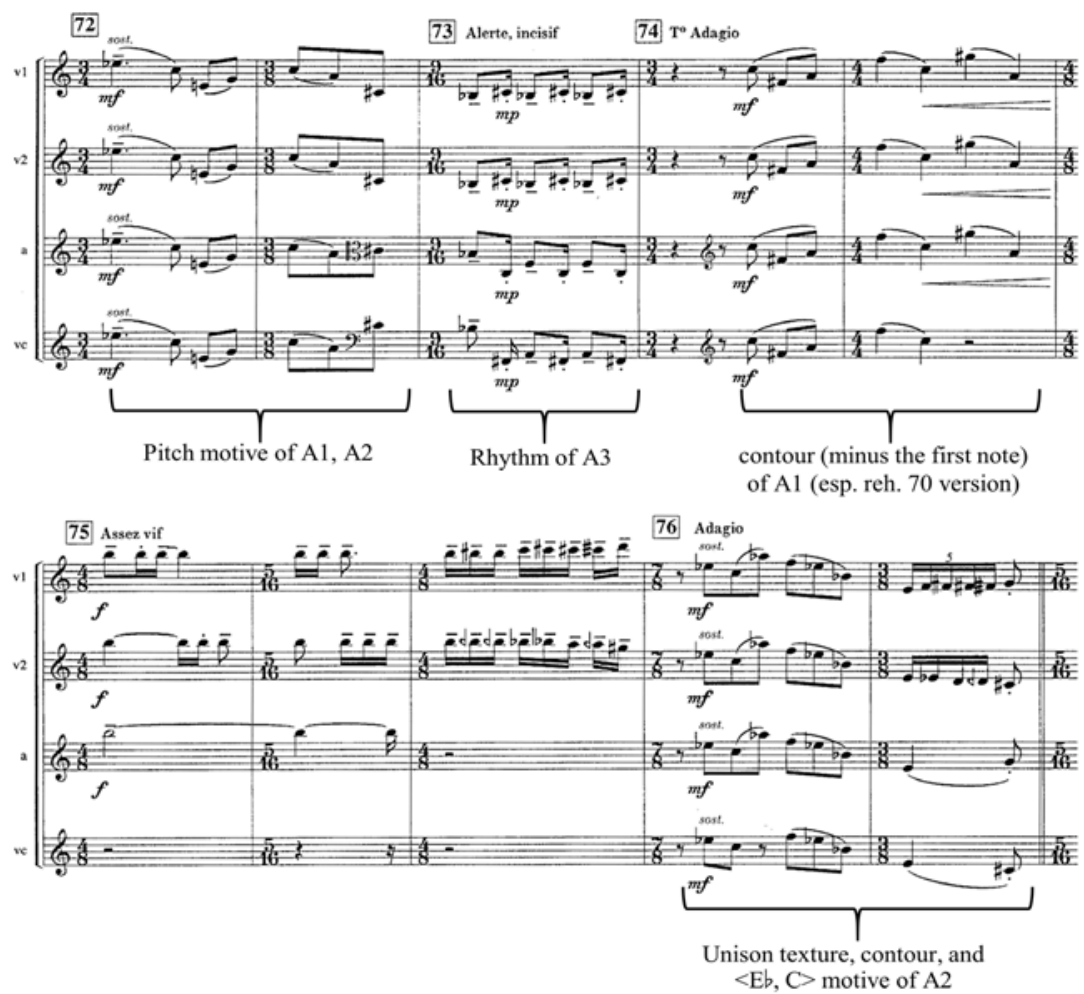

Figure 21. Rehearsals 72 through 76.

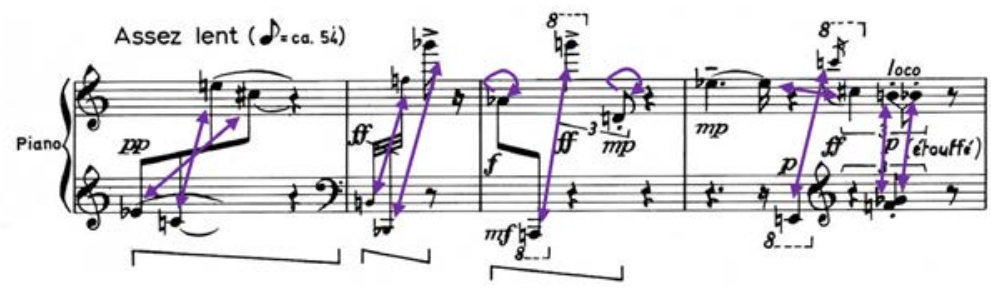

Figure 22. Gilles Tremblay, Phases, $\mathrm{I}_{4}$ relations in measures 1-4.

We have seen that variation is the most integral structural component throughout the work, creating the core of new motivic material, occurring not simply as adornments of the main motivic statement, but as a layered process of developing variation. As these variations accumulate, new motives are created from older ones, which can help lead to a sense of unity in the work; the identity of the motive does not reside in one particular element, but rather mutates progressively throughout the piece. However, a key component to recognizing this progressive process is the retention of one or more elements in a 

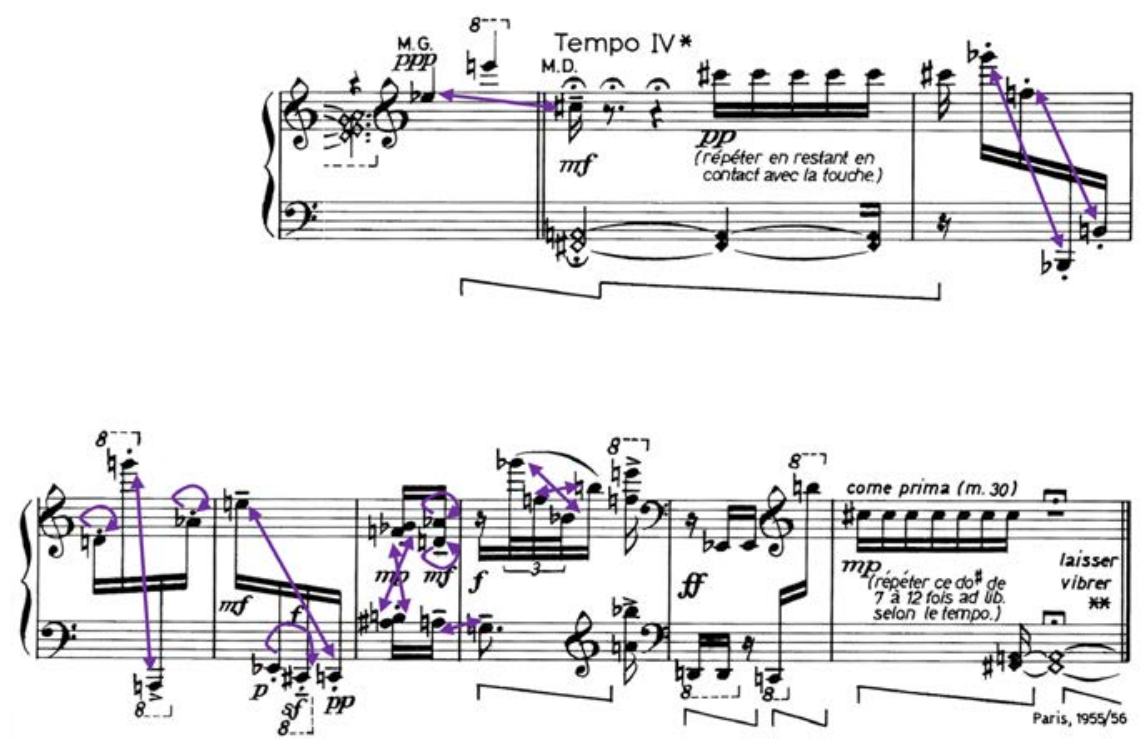

* Ecouter les battements du do et en prendre le tempo ( $\mathcal{A}^{\beta}$ un battement) pour la musique qui suit jusqu'à la fin. (Si ces battements sont trop lent, en doubler le tempo.)

** L'ondulation doit avoir la mếme vitesse que la ${ }^{\prime}$ de la musique qui précède.

Figure 23. Gilles Tremblay, Phases, measures 29-37 (arrows indicate $\mathrm{I}_{4}$ relationships).

passage. In a context where tonality is absent, other elements such as contour, transformational process, and rhythm become particularly important features of similarity. What we have observed in Croissant suggests that a more suitable understanding of this work (and perhaps of other contemporary repertoire) requires a holistic rather than a more local, small-scale focus.

\section{REFERENCES}

Canadian Music Centre. 2003. "Gilles Tremblay." Canadian Music Centre. http://www.musiccentre.ca/node/37334/biography.

Cornfield, Eitan. 2003. "Tremblay Documentary" (interview with Gilles Trem-

blay). Canadian Composer Portraits: Gilles Tremblay, Centrediscs. Audio.

CD 789.

Dahlhaus, Carl. 1987. Schoenberg and the New Music. Translated by Derrick

Puffett and Alfred Clayton. Cambridge: Cambridge University Press.

d'Indy, Vincent. 1909. Cours de composition musicale, livre 2, partie 1. Edited with Auguste Sérieyx. Paris: Durand et Cie.

Frisch, Walter. 1984. Brahms and the Principle of Developing Variation. Berkeley: University of California Press.

- 1992. "Brahms, Developing Variation, and the Schoenberg Critical Tradition." 19th-Century Music 5 (3): 215-32.

Haimo, Ethan. 1997. "Developing Variation and Schoenberg's Serial Music."

Music Analysis 16 (3): 349-65. 
Hesketh, Kenneth. 2010. "The Backbone of Night: Mechanisms of Evolution in Henri Dutilleux's Ainsi la nuit." Contemporary Music Review 29 (5): 463-83.

Lefebvre, Marie-Thérèse. 2011. "Compléments biographiques: pour la suite des recherches autour de l'œuvre de Gilles Tremblay." Circuit: musiques contemporaines 20 (3): 91-103.

Lerdahl, Fred. 1999. "Composing Notes." Current Musicology 67/68:243-51.

- 2001. Tonal Pitch Space. Oxford: Oxford University Press.

Lerdahl, Fred, and Ray Jackendoff. 1985. A Generative Theory of Tonal Music. Cambridge, MA: MIT Press.

Lewin, David. 1987. Generalized Musical Intervals and Transformations. New Haven, CT: Yale University.

Lind, Stephanie. 2008a. "Interpreting Gesture as Motive: A Transformational Perspective on Recursion and Replication in R. Murray Schafer's Seventh String Quartet.” Intersections 28 (2): 51-71.

_. 2008b. "Replicative Network Structures: Theoretical Definitions and Analytical Applications." Ph.D. diss., The University of British Columbia, 2008.

Messier, Irène, and Anne Marie Messier. 2006. "Interview with Gilles Tremblay." Composer?! 12 Portraits, vol. 1, DVD. Montreal: Société de musique contemporaine du Québec.

Morris, Robert D. 1993. "New Directions in the Theory and Analysis of Musical Contour." Music Theory Spectrum 15 (2): 205-28.

Nichols, Roger, and Henri Dutilleux. 1994. "Progressive Growth: Henri Dutilleux in Conversation with Roger Nichols." Musical Times 135 (1812): 87-90.

Provost, Serge. 2011. "Gilles Tremblay: éléments d'une poétique musicale vus sous le prisme de Réseaux, Fleuves et Solstices." Circuit: musiques contemporaines 20 (3): 105-20.

Quinn, Ian. 1997. "Fuzzy Extensions to the Theory of Contour." Music Theory Spectrum 19 (2): 232-63.

Ranallo, Vincent. 2011. “Une célébration sonore de l'Esprit : à propos d'Oralléluiants." Circuit: musiques contemporaines 20 (3): 43-58.

Richard, Robert. 2006. "Gilles Tremblay." In Encyclopedia of Music in Canada, online edition. Edited in 2013. http://www.thecanadianencyclopedia.ca/ en/article/gilles-tremblay-emc.

Roeder, John. 2009. "Animating the Inside: Introduction." Music Theory Online 15 (1). http://www.mtosmt.org/issues/mto.09.15.1/mto.09.15.1.roeder_ intro.html.

Rufer, Josef. 1954. Composition with Twelve Tones. Translated by Humphrey Searle. London: Barrie and Rockliff.

Schaeffer, Julius. 1860. "A. Sarah, op. 1: Phantasie-Variationen für Pianoforte." Neue Zeitschrift für Musik 27, no. 52 (16 March 1860): 105-6. Translation from “On Variations," Dwight's Journal of Music, 15 April 1865.

Schoenberg, Arnold. 1960. "The Orchestral Variations, Op. 31: A Radio Talk." Score 27: 27-40. 
- 1965. Letters. Selected and edited by Erwin Stein. Translated by Eithne Wilkins and Ernst Kaiser. New York: St. Martin's.

- 1967. Fundamentals of Musical Composition. Edited by Gerald Strang and Leonard Stein. London: Faber \& Faber, Inc.

- 1975. Style and Idea: Selected Writings of Arnold Schoenberg. Edited by Leonard Stein, with translations by Leo Black. New York: St. Martin's.

Société de musique contemporaine du Québec (SMCQ). 2012. "Gilles Tremblay reçoit une nomination de l'Ordre du Canada." http:// smcq.qc.ca/smcq/fr/nouvelle/10241/Gilles Tremblay reçoit une nomination_de_l_Ordre_du_Canada.

- 2017. "Gilles Tremblay: Une contribution exceptionnelle." http://www.smcq.qc.ca/smcq/fr/nouvelle/10441/Gilles Tremblay _Une_contribution_exceptionnelle

_ n.d. "Biography: Gilles Tremblay." http://smcq.qc.ca/smcq/en/artiste/ tremblay gi/Gilles Tremblay/biographie.

Straus, Joseph. 2003. "Uniformity, Balance, and Smoothness in Atonal Voice-Leading." Music Theory Spectrum 25 (2): 305-52.

-2016. Introduction to Post-Tonal Theory. 4th ed. New York: W.W. Norton. Tremblay, Gilles. 1994. "Un pays à faire: le compositeur Gilles Tremblay a refusé l'Ordre du Canada." Circuit: musiques contemporaines 5 (1): 59-60.

__ 1995a. "Émergence de la forme dans la matière: de Varèse à Mozart." Circuit: musiques contemporaines 6 (1): 37-42.

__ 1995b. "Les Vêpres de la Vierge (Tremblay)." Circuit: musiques contemporaines $6(1)$ : 51-6.

_. 1995c. "Notes pour Cantique de durées (Tremblay)." Circuit: musiques contemporaines (1): 43-50.

Trottier, Danick. 2010. "Gilles Tremblay pédagogue vu par ses anciens élèves: questionnaire réalisé par courriel." Circuit: musiques contemporaines 20 (3): 73-90.

Tymoczko, Dmitri. 2009. "Generalizing Musical Intervals." Journal of Music Theory 53 (2): 227-54.

— 2011. A Geometry of Music. Oxford: Oxford University Press.

\begin{abstract}
Gilles Tremblay, considered one of the forefathers of contemporary music in Quebec, is primarily known for a focus on rhythm, sonority, and aleatoric processes. This article explores another unexplored aspect of Tremblay's composition: motivic development through developing variation. Beginning with a discussion of the historical antecedents of this style in the work of Schoenberg, d'Indy, and Dutilleux, the article analyzes Tremblay's use of developing variation in his string quartet, Croissant, through the lens of transformational theory.
\end{abstract}




\section{RÉSUMÉ}

Gilles Tremblay, considéré comme l'un des précurseurs de la musique contemporaine au Québec, est d'abord connu pour son attention au rythme, à la sonorité, et aux processus aléatoires. Cet article explore un aspect ignoré de la technique compositionnelle de Tremblay: le développement motivique par variation développante. À partir d'une discussion sur les antécédents historiques de ce style dans l'œuvre de Schoenberg, d'Indy, et Dutilleux, cet article analyse l'utilisation faite par Tremblay de la variation développante dans son quatuor à cordes, Croissant, à travers le prisme de la théorie transformationnelle.

\section{BIOGRAPHY}

Stephanie Lind is an associate professor at the Dan School of Drama and Music, Queen's University. Her research interests include the music of contemporary Quebecois composers, transformational theory, and the music of video games. Publications include articles in Intersections, Perspectives of New Music, Music Theory Online, and most recently a book chapter in Music Video Games: Performance, Politics, and Play. 